J. Clin. Chem. Clin. Biochem.

Vol. 23, 1985, pp. $377-380$

\title{
Pancreatic B-Cell Peptides as Parameters for Diagnosis and Localisation of Hormone Secreting Tumours
}

\author{
By K.-D. Gerbitz \\ Institut für Klinische Chemie und Forschergruppe Diabetes, Städt. Krankenhaus Schwabing. München \\ F. Spelsberg
}

Chirurg. Abt., Krankenhaus Martha-Maria, München

Simone Bach, Irene Schumacher and Barbara Boenke

Institut für Klinische Chemie und Forschergruppe Diabetes, Städt. Krankenhaus Schwabing, München

(Received November 12, 1984/March 7, 1985)

\begin{abstract}
Summary: Insulin, C-peptide and proinsulin were measured in peripheral blood of 11 patients suffering from different types of hormone-producing pancreatic B-cell tumours. While proinsulin was elevated in 10/11 patients during prolonged fasting, C-peptide and insulin levels were found within the reference range in $5 /$ 11 and $3 / 5$ cases respectively. A rapid insulin assay performed during surgery was helpful for localisation and identification of the respective tumours.
\end{abstract}

\section{B-Zellpeptide als Kenngrößen zur Diagnostik und Lokalisation von Insulinomen}

Zusammenfassung: Insulin, C-Peptid und Proinsulin wurden bei 11 Patienten mit unterschiedlichen Formen von B-Zelltumoren gemessen. Proinsulin fand sich in 10/11 Patienten, C-Peptid in 5/11 und Insulin in 2/5 Fällen erhöht. Ein intraoperativ durchgeführter Insulinschnelltest erwies sich als hilfreich zur Lokalisation und Identifikation der entsprechenden Tumoren.

\section{Introduction}

Hypoglycaemia is an unspecific symptom of quite different diseases, including hormone-producing Bcell tumours. Diagnosis of the latter is sometimes difficult. Blood glucose measurements during prolonged fasting, calcium infusion and other provocative and suppressive tests are used to confirm the diagnosis, but the existence of an insulinoma is substantiated only by elevated serum concentrations of the B-cell peptides insulin, C-peptide and/or proinsulin. Here we report our experience in the diagnosis of 10 hormone-producing B-cell tumours and 1 case of nesidioblastosis during the last three years.

\section{Materials and Methods}

Patients with neuroglucopenic symptoms are subjected to the following diagnostic procedure (1): First, a prolonged (5 hours) oral glucose tolerance test is performed to exclude a reactive hypoglycaemia. The crucial test is prolonged fasting, if possible, over a period of 72 hours. During this time blood glucose is measured at least every four to six hours. For determination of B-cell peptides, peripheral blood is drawn at the same time, but assays are done only if the blood sugar concentrations decrease below $500 \mathrm{mg} / \mathrm{l}$. This cut-off point is chosen for two reasons: first, for the patients it avoids the danger of severe hypoglycaemic attacks; secondly, in our experience maintainance of the glucose balance at levels above $500 \mathrm{mg} / \mathrm{l}$ excludes the existence of a hormone-producing B-cell tumour.

Insulin was measured as described (2) using a guinea pig antiinsulin serum prepared in our laboratory. C-peptide was 
determined by a commercial assay (Behring-Werke, Marburg), and proinsulin by the procedure described by Heding (3). Sepharose-coupled insulin antibodies cross-reacting with proinsulin were prepared according to l.c. (3). The anti-C-peptide serum was the NOVO M 1219 serum, kindly provided by $L$. Heding. Three different types of human proinsulin standards were used: first, a pancreatic human proinsulin prepared in 1970 at the University of Chicago (4) and kindly donated by $D$. Steiner; secondly, human proinsulin material purified in our laboratory from a human insulinoma; thirdly, a new human proinsulin highly purified from b-component at the NOVO Research Institute and kindly provided by $V$. Kruse. The evaluation data for this latter standard material were published recently (5). Identical values were obtained when the new Novo proinsulin standard was compared with biosynthetic human proinsulin made by recombinant DNA technology (6). On the basis of these results, the proinsulin values obtained by use of the old "Chicago"-standard as well as by use of our own standard are overestimated by a factor of three. Thus all proinsulin concentrations measured with the old standard are corrected for this factor.

In some cases B-cell tumours are not detectable by other methods such as coeliacography, abdominal computerized axial tomography and sonography. Although in most of these cases the operating surgeon is able to localize the tumour by palpation, we generally substantiate his finding by insulin measurements in samples obtained during surgery (7). For this purpose a catheter is inserted into the vena lienalis near the spleen hilus and carefully pushed forward into the vena portae.
A

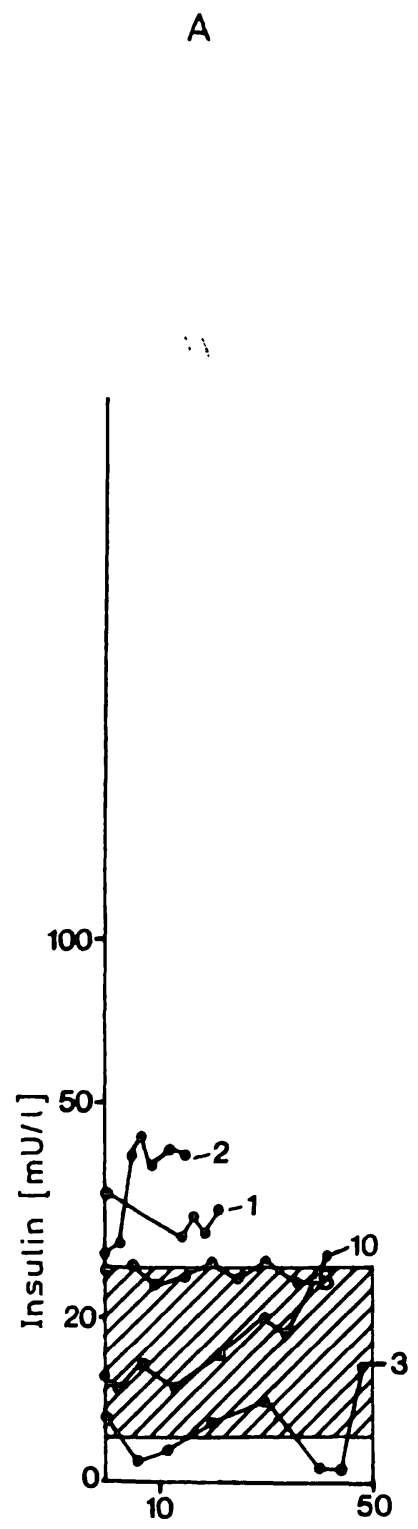

B

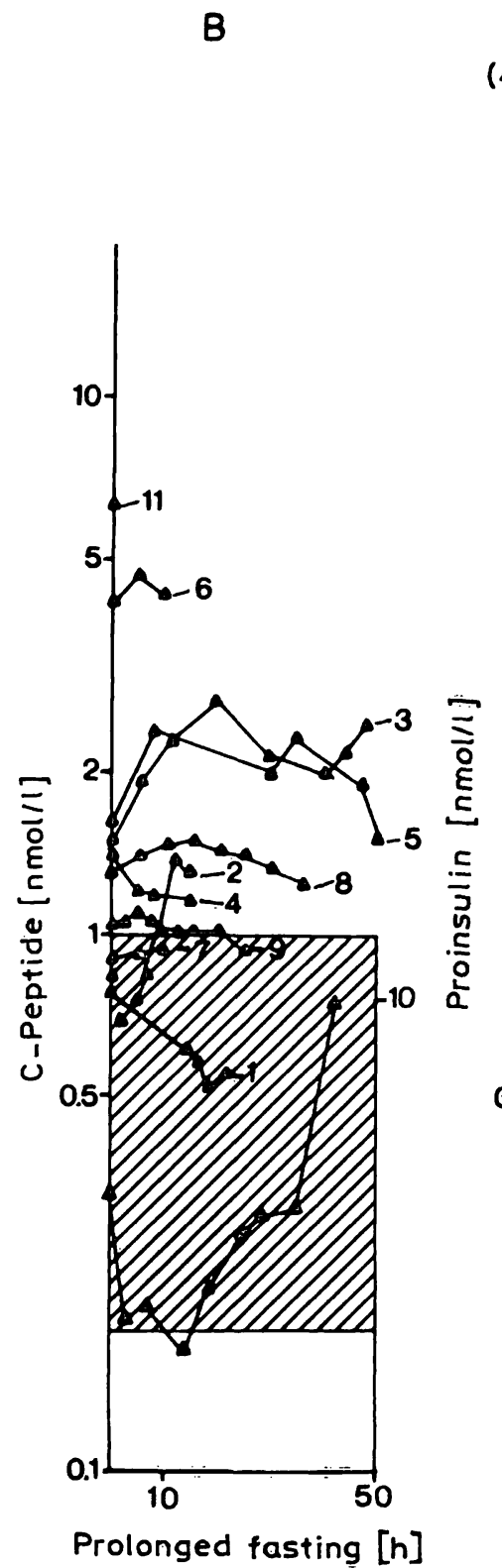

Prolonged fasting [h]

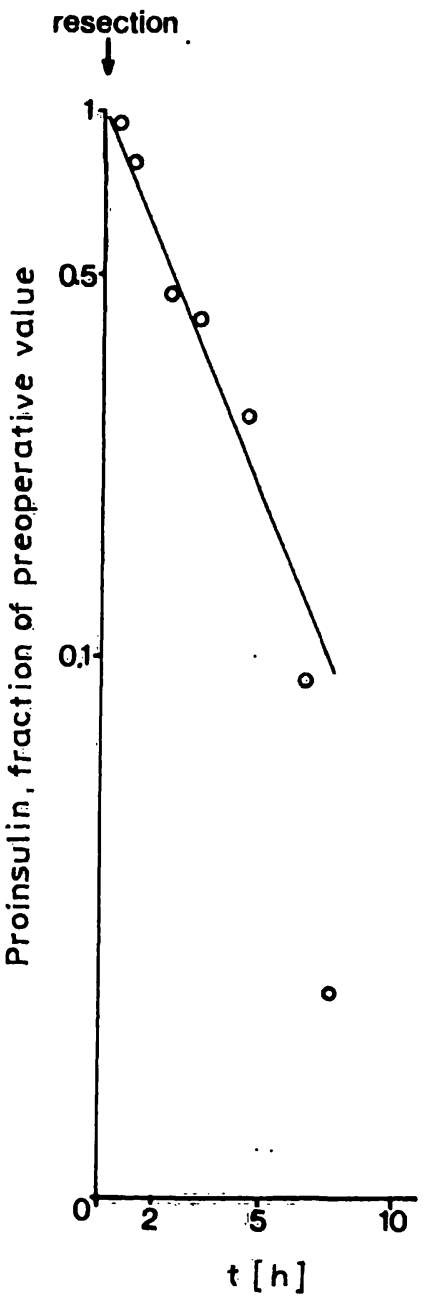

Fig. 1. (A-C). Measurement of insulin (A), C-peptide (B) and proinsulin (C) during prolonged fasting.

The numerical order of the patients corresponds to that in the table. Prolonged fasting was interrupted when blood glucose concentration had decreased below $500 \mathrm{mg} / \mathrm{l}$. Note the logaririthmic scale. Each point represents the mean of two determinations. The shaded areas represent the reference ranges obtained in healthy subjects after overnight fasting (1). Proinsulin concentrations are corrected for the new purified standard material according to 1 . c. (5).

Fig. 1 (D). Proinsulin in serum of Pat. 9 after resection of an insulinoma (single determinations): The proinsulin concentration measured immediately before removal of the tumour isj; set at 1 . 
Then the catheter is retracted and heparinized blood is drawn at each $\mathrm{cm}$ distance. Insulin is measured in triplicate using a rapid assay. Briefly the assay procedure is as follows: incubation of insulin standards or unknown plasma samples $(150 \mu \mathrm{l})$ for 15 minutes at room temperature with trace amounts of bovine [125I]insulin (about 10000 counts/min $\cdot 50 \mu l$ ) together with a guinea pig antiinsulin serum $(100, \mu)$ of high titer (final dilution 1:400000). Following incubation, $50 \mu \mathrm{l}(50 \mathrm{mg})$ of human $\gamma$ globulin (Beriglobin ${ }^{\oplus}$ ) is added and immediately thereafter the mixture is precipitated by adding $250 \mu$ l of a solution of 250 g/l polyethyleneglycol (PEG 6000, Merck, Darmstadt). After centrifugation in an Eppendorf centrifuge for two minutes, the supernatant is decanted and the pellet is counted in a Nuclear Enterprise NE $1600 \gamma$-counter. The assay has a within-run precision $(n=20)$ of $18 \%(C V)$.

\section{Results}

Figure 1 demonstrates the diagnostic power of the three B-cell peptides during prolonged fasting of 10 patients suffering from B-cell adenomas or islet cell carcinomas. A single determination of $\mathrm{C}$-peptide and proinsulin in a case of nesidioblastosis is also shown. Insulin was found to be elevated only in 2 out of 5 patients with insulinomas. In 5/11, C-peptide values were within or at the upper level of the reference range, while in $6 / 11$ the values were increased $2-5$ fold. In 10/11 cases a single proinsulin determination confirmed the diagnosis. In these cases proinsulin concentrations were elevated $4-50$ fold above the upper level of the reference range. In the newborn suffering from nesidioblastosis greatly elevated proinsulin values were found.

Figure 1 also demonstrates the normalisation of the proinsulin levels in the serum of one patient (patient 9) after surgery and resection of the insulinoma. From the data shown, an apparent in vivo half-life of proinsulin of about 120 minutes can be calculated, which is higher than reported in the literature (2).

Tab. 1. Clinical data.

\begin{tabular}{lllll}
\hline Number & Initials & Sex & $\begin{array}{l}\text { Age } \\
\text { (years) }\end{array}$ & Tumour \\
\hline $1 .$. & S.T. & $\$$ & 38 & adenoma \\
2 & S.C. & $\$$ & 76 & adenoma \\
3 & S.U. & 0 & 57 & multiple adenomas \\
4 & K.U. & 0 & 47 & adenoma \\
5 & N.E. & $\$$ & 56 & adenoma \\
6 & B.I. & $\delta$ & 79 & B-cell carcinoma \\
7 & M.A. & $\$$ & 39 & 2 adenomas \\
8 & A.N. & $\$$ & 38 & adenoma \\
9 & S.O. & 0 & 47 & adenoma \\
10 & W.D. & $\$$ & 26 & adenoma \\
11 & H.U. & $\$$ & newborn & nesidioblastosis \\
\hline
\end{tabular}

* The patient was diagnosed (Dr. U. Walter) and operated at the University of Würzburg.

\section{Localisation of the tumour during surgery}

An example of the localisation of the tumour by measurements of insulin during surgery is given in figure 2. The scheme demonstrates the in situ situation together with the insulin concentrations in plasma samples obtained by catheterization. Although the operating surgeon (F.S.) had already palpated two tumours, insulin measurements confirmed the presence of two distinct B-cell adenomas.

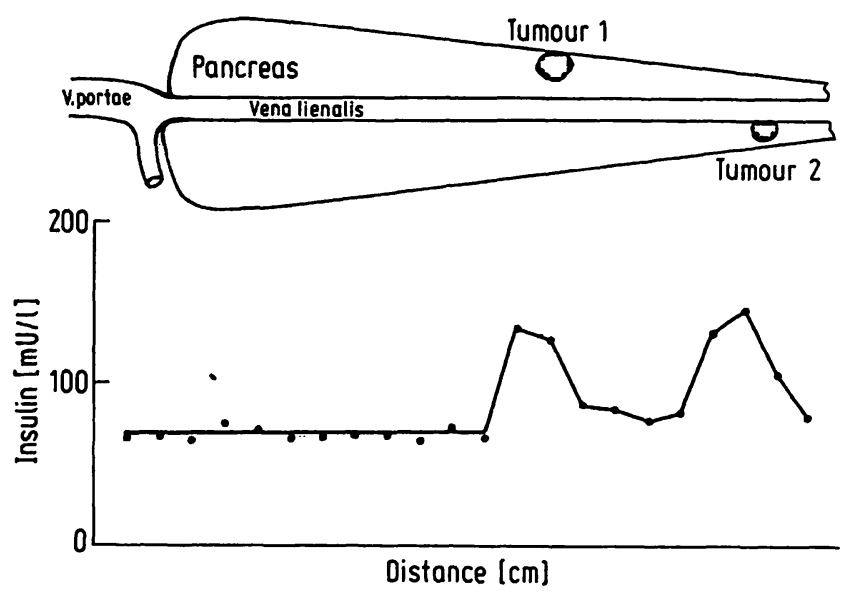

Fig. 2. Upper part: schematic localisation of the two adenomas in situ (patient 7, M.A.).

Lower part: insulin concentrations in plasma samples obtained by catherization of the v. lienalis. Each point represents the mean of three determinations.

\section{Discussion}

Frequent neuroglucopenic symptoms usually lead to the diagnostic search for an insulinoma. Although the diagnostic procedures have been greatly improved, it is possible for a patient to suffer for years from a slowly growing tumour before the correct diagnosis is substantiated (8). The development of radioimmunological methods for the determination of the B-cell peptides, insulin, C-peptide and proinsulin made it possible to measure tissue specific antigens. Differences in tissue content, secretion pattern and plasma half-life of these antigens, however, are to be expected, and they do not have the same diagnostic value. The value of insulin measurements is mainly a function of the upper level of the reference range employed, which again is dependent on the short half-life of insulin and other influences such as age, sex, body weight etc. The same is true for the corrected insulin/glucose quotient introduced by Turner et al. (9). Reports in the literature about the 
diagnostic sensitivity of insulin for the diagnosis of an insulinoma differ accordingly (8). Before we introduced the C-peptide and proinsulin methods only about $50 \%$ of our insulinoma patients were diagnosed immediately from insulin measurements during prolonged fasting. It was hoped that the C-peptide assay would further improve the diagnostic procedure. However in the recent report published by Heding \& Kruse (10) on 206 sera from fasting insulinoma patients, elevated C-peptide levels are found in only $50 \%$, which is consistent with the present results. The use of both assays, i.e. insulin and Cpeptide, clearly improves the diagnostic evidence.

Probably due to a reduced storage capacity of the tumour cell (11) and its autonomous secretion, insulinoma patients in general have elevated proinsulin levels in their serum $(2,3,10-13)$. In the above mentioned study (10) only $2 / 206$ sera from insulinoma patients had proinsulin concentrations within the reference range, which is consistent with results reported here on a much smaller group of patients. Thus the diagnostic sensitivity of the proinsulin determination is over $90 \%$. Possibly our one insulinoma patient with normal fasting proinsulin concentrations is similar to the case recently reported by Pichl et al. (14), in which hormone secretion by an insulinoma showed periodicity. With respect to the diagnostic specificity of the proinsulin determination, further studies are needed. Hyperproinsulinaemia is found in patients with thyrotoxicosis (15) and with cirrhosis (16).

The observed increase in the plasma half-life of proinsulin in patient 9 might be caused by the fact that hyperproinsulinaemia in such patients is not only a result of hypersecretion of the autonomous tumour, but is additionally amplified by decreased peripheral degradation (17). Intraoperatively, about 20 percent of the insulinomas are not detected by inspection or bidigital palpation. Furthermore, in about 12 percent of cases, multiple adenomas are found (18). Thus tumour localisation either by preoperative transhepatic catherisation $(19,20)$ or intraoperatively by direct catherisation of the vena lienalis $(7,21)$ is absolutely necessary. Since the latter method is less dangerous for the patient and the rapid insulin assay needs only about 20 minutes, we prefer the direct catherisation during surgery.

\section{Acknowledgement}

This work was supported in part by the Stiftung Deutsche Krebshilfe. We thank Dr. U. Walter (University of Würzburg) who allowed us to investigate the blood samples of patient 10 .

\section{References}

1. Gerbitz, K.-D. (1982) Klinikarzt 11, 397-402.

2. Gerbitz, K.-D. (1980) J. Clin. Chem. Clin. Biochem. 18, $313-316$.

3. Heding, L. (1977) Diabetologia 13, 467-474.

4. Rubenstein, A. H. \& Steiner, D. (1970) In: Early Diabetes (Camerini-Davalos, R. A. \& Cole, H. S., eds.) Academic Press, New York, pp. 159-166.

5. Kruse, V., Heding, L. G., Jørgensen, K. H., Tronier, B., Christensen, M., Thim, L., Frank, B. H., Root, M. A., Cohen, R. M. \& Rubenstein, A. H. (1984) Diabetologia 27, 414-415.

6. Frank, B. H., Pettee, J. M., Zimmerman, R. E. \& Burck, P. J. (1981) In: Peptides: Synthesis-structure-function (Rich, D. H. \& Gross, E., eds.) Pierce Chemicals, Rockford, Illinois, pp. 729-738.

7. Teichmann, R. K., Wirsching, R. \& Spelsberg, F. (1980) Eur. Surg. Res. 12, (Suppl. 2) 33.

8. Creutzfeldt, W. \& Arnold, R. (1979) Internist 20, 382-391.

9. Turner, R. C., Oakley, N. W. \& Nabarro, I. D. M. (1971) Brit. Med. J. II, 132-134.

10. Heding, L. G. \& Kruse, V. (1984) Diabetes 33, 148A (Abstract).

11. Creutzfeldt, W., Arnold, R., Creutzfeldt, C., Deuticke, U., Frerichs, H. \& Track, N. S. (1973) Diabetologia 9, $217-231$.

12. Heding, L. G., Faber, O., Kaperska-Czyzykowa, T., Sestoft, L. \& Turner, R. C. (1979) In: Proinsulin, Insulin and CPeptide (Baba, S., Kaneko, T. \& Yanaihara, N. eds.) Excerpta Medica, Amsterdam-Oxford pp. 254-261.

13. Turner, R. C. \& Heding, L. G. (1977) Diabetologia 13, $571-574$.

14. Pichl, J., Domschke, W., Schnück, R., Grall, F. P. \& Hartmann, F. (1984) Dtsch. Med. Wochenschri. 109, $1543-1544$.

15. Sestoft, L. \& Heding, L. G. (1981) Diabetologia 21, $103-107$.

16. Kaperska-Czyzykowa, $\overline{\mathrm{T}}$., Heding, L. G. \& Czyzyk, A. (1983) Diabetologia 25, 506-509.

17. Villaume, C., Beck, B., Pointel, I. P., Drouin, P. \& Debry, G. (1982) J. Endocrinol. Invest. 5, 315-321.

18. Spelsberg, F., Landgraf, R., Wirsching, R. \& Heberer, G. (1978) Münch. Med. Wochenschr. 120, 547-552.

19. Ingemanson, S., Kühl, C., Larsson, L. I., Lunderquist, A. \& Lundquist, I. (1978) Surg. Gynecol. Obstet 146, 725-734.

20. Rückert, K., Günther, R. \& Kümmerle, F. (1980) Chirurgie $51,32-34$

21. Turner, R. C., Lee, E. C. G., Morris, P. J., Harris, E. A. \& Dick, R. (1978) Lancet $I, 515-518$. '

Priv. Doz. Dr. K.-D. Gerbitz

Institut für Klinische Čhemie

Städt. Krankenhaus München-Schwabing

Kölner Platz 1

D-8000 München 40: 